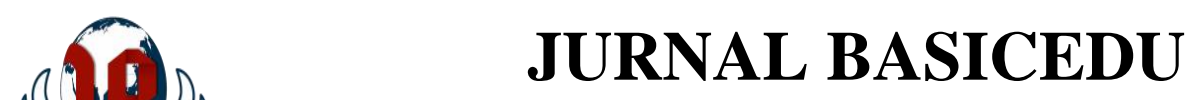

Volume 5 Nomor 2 Tahun 2021 Halaman 1046 - 1059

Research \& Learning in Elementary Education https://jbasic.org/index.php/basicedu

PAIERSITAS

\title{
Pengembangan Media Pembelajaran Kodig Untuk Meningkatkan Prestasi Belajar Siswa di Sekolah Dasar
}

\author{
Unik Kurniawati $^{1 \bowtie}$, Henny Dewi Koeswanti ${ }^{2}$ \\ Program Studi Pendidikan Guru Sekolah Dasar, Universitas Kristen Satya Wacana ${ }^{1,2}$ \\ E-mail: 292017136@ @ student.uksw.edu ${ }^{1}, \underline{\text { Henny.Koeswanti@uksw.edu }}{ }^{2}$
}

\begin{abstract}
Abstrak
Proses pembelajaran yang baik tidak menjadikan guru sebagai satu-satunya sumber belajar, diperlukan berbagai sumber belajar penunjang, seperti yang tertuang dalam Prinsip Standar Proses Pembelajaran menurut Permendikbud Nomor 22 Tahun 2016 salah satunya yaitu dari guru sebagai satu-satunya sumber belajar menjadi belajar berbasis aneka sumber belajar. Permasalahan yang dihadapi salah satunya adalah guru tidak memanfaatkan media pembelajaran, guru hanya memberi materi yang diperlukan melalui metode ceramah. Terlebih ketika pembelajaran daring, siswa memerlukan media untuk membantu mempermudah penerimaan materi. Penelitian dilakukan untuk mengembangkan media pembelajaran kodig (komik digital) untuk meningkatkan prestasi belajar tema 6 subtema 1 pada siswa kelas V. Penelitian dilakukan dengan menggunakan jenis penelitian dan pengembangan (Research and Development) atau dapat disingkat dengan R\&D. Model yang digunakan dalam penelitian menggunakan model Sukmadinata, dan model pengembangan ADDIE yang melalui beberapa tahap yaitu tahap analisis, perancangan, pengembangan, implementasi, dan evaluasi. Penelitian dilakukan hingga tahap pengembangan. Uji validasi ahli materi memeroleh persentase sebesar $84 \%$ dengan kriteria sangat tinggi, sedangkan uji validasi ahli media memeroleh persentase sebesar $77 \%$ dengan kriteria tinggi. Maka dapat disimpulkan bahwa media pembelajaran kodig(komik digital) layak digunakan untuk meningkatkan prestasi belajar tema 6 subtema 1 pada siswa kelas V.
\end{abstract}

Kata Kunci: media pembelajaran, komik digital, prestasi belajar

\begin{abstract}
A good learning process does not make the teacher the only source of the learning, it requires a variety of supporting learning sources, as stated in the Standard Principles of the Learning Process according to Permendikbud No. 22 of 2016 one of which is from the teacher as the only source of learning to learning based on various learning sources. One of the problems faced is that the teacher does not use learning media, teachers only carry out the learning using the lecturing method. In online learning, students need media to help them to understand the materials. The research was conducted to develop learning media for codig (digital comics) to improve learning outcomes on the theme of 6 sub-themes 1 in class $V$. The research was conducted using Research and Development $(R \& D)$. The model used in the study was the Sukmadinata model, and the ADDIE development model which went through several stages, namely the analysis, design, development, implementation, and evaluation stages. The research was carried out until the development stage. The material expert validation test obtained a percentage of $84 \%$ with very high criteria, while the media expert validation test obtained a percentage of $77 \%$ with high criteria. So it can be concluded that the Kodig learning media (digital comics) is feasible to use to improve learning outcomes on theme 6 sub-theme 1 in class $V$.

Keywords: learning media, digital comics, learning outcomes.
\end{abstract}

Copyright (c) 2021 Unik Kurniawati, Henny Dewi Koeswanti

Corresponding author :

Email:292017136@student.uksw.edu

DOI : https://doi.org/10.31004/basicedu.v5i2.843

ISSN 2580-3735 (Media Cetak)

ISSN 2580-1147 (Media Online) 
1047 Pengembangan Media Pembelajaran Kodig Untuk Meningkatkan Prestasi Belajar Siswa di Sekolah Dasar - Unik Kurniawati, Henny Dewi Koeswanti

DOI : https://doi.org/10.31004/basicedu.v5i2.843

\section{PENDAHULUAN}

Pada observasi yang dilakukan, ditemukan beberapa fakta, bahwa: (1) Media pembelajaran yang digunakan hanya buku tema dan LKS, guru menjelaskan materi sesuai dengan yang ada di buku lalu meminta siswa mengerjakan tugas yang ada di buku tema atau LKS. (2) Materi tidak diajarkan terlebih dahulu. Terkadang guru hanya meminta siswa untuk mengerjakan tugas lalu mengirimkan hasilnya begitu saja tanpa adanya penjelasan mengenai materi yang diajarkan. (3) Kurangnya motivasi dan minat siswa serta timbulnya rasa bosan dalam belajar terkait pembelajaran monoton yang dilakukan guru.

Berdasarkan permasalahan yang terdapat di sekolah, maka hal yang bisa dilakukan untuk membantu proses pembelajaran yaitu merancang media pembelajaran yang kreatif untuk menunjang proses pembelajaran yang berlangsung. Media pembelajaran komik dgital akan membantu siswa dalam belajar dan memahami materi pembelajaran, terlebih dapat meningkatkan motivasi serta kemauan siswa untuk belajar.

Penelitian dilakukan dengan tujuan (1) Untuk mengetahui desain pengembangan media pembelajaran komik digital yang dapat meningkatkan prestasi belajar siswa. (2) Mengetahui tingkat validitas media pembelajaran komik digital dalam meningkatkan prestasi belajar siswa.

Sesuai dengan kajian teori, beberapa hasil penelitian yang relevan yaitu penelitian yang dilakukan oleh (Wardana, 2018:91) berdasarkan hasil hasil validasi tiga ahli media memperoleh nilai rata-rata 92,91\%, tiga ahli materi memperoleh nilai rata-rata 87,87 , dan dua respon pendidik memperoleh nilai rata-rata 92,59. Sehingga hasil dari penelitian tersebut menunjukkan bahwa komik merupakan media pembelajaran yang baik digunakan dalam proses pembelajaran. Selanjutnya validasi yang dilakukan oleh (Andra, 2018:49) menunjukkan hasil yang baik yaitu dengan hasil validasi media $72 \%$ dan hasil validasi materi $74 \%$, sehingga menunjukkan bahwa media komik layak digunakan sebagai sarana penguatan nilai karakter siswa dalam pembelajaran. Begitu pula dengan penelitian yang dilakukan oleh (Hidayah, 2017:45-46) yang menyatakan bahwa kualitas produk pembelajaran berbasis komik pada mata pelajaran IPS materi koperasi sangat baik digunakan berdasarkan hasil validasi 3 ahli materi, 3 ahli media, dan 3 guru. Respon dari peserta didik juga sangat layak dilihat dari tanggapan pada angket yang diberikan.

Selanjutnya berdasarkan hasil penelitian dari (Ambaryani, 2017:64) menyimpulkan bahwa media komik berhasil meningkatkan hasil belajar siswa pada mata pelajaran IPA di kelas IV SD. Sama halnya dengan penelitian yang dilakukan oleh (Kristiani, 2017:64) yang menyatakan bahwa media pembelajaran komik dapat meningkatkan hasil belajar peserta didik pada pembelajaran matematika pada materi pecahan di kelas V SD. Begitu pula dengan penelitian yang dilakukan oleh (Mentari, 2017:47) yang menunjukkan bahwa komik edukasi efektif digunakan dalam proses pembelajaran.

Terlebih dahulu dapat kita ketahui bahwa pembelajaran yang diberikan adalah pembelajaran tematik. Menurut (Prastowo, 2013:117) bahwa pembelajaran tematik merupakan pembelajaran yang dirancang berdasarkan tema-tema tertentu. Lalu karakteristik pembelajaran tematik menurut (Departemen Pendidikan Nasional, 2006:6) yaitu pembelajaran yang berpusat pada siswa, memberikan pengalaman langsung, terdapat pemisahan mata pelajaran yang tidak begitu jelas, pembelajaran yang menyajikan konsep dari berbagai mata pelajaran, bersifat fleksibel, hasil pembelajaran sesuai dengan minat dan kebutuhan siswa, menggunakan prinsip belajar sambil bermain dan menyenangkan. Pengertian media menurut (Arsyad, 2011:3) bahwa secara harafiah, media berasal dari Bahasa Latin “medius" yang artinya 'tengah', 'perantara' atau 'pengantar'. Maka dapat diketahui bahwa media merupakan alat penghubung untuk menyampaikan sesuatu. Ungkapan Hamalik (dalam Arsyad, 2011:15) yang mengemukakan bahwa penggunaan media pembelajaran dalam proses pembelajaran dapat membangkitkan keinginan dan minat yang baru, membangkitkan motivasi dan rangsangan kegiatan belajar, dan bahkan membawa pengaruh-pengaruh psikologis terhadap siswa. Menurut (Gumelar, 2011:7) dalam bukunya Comic Making bahwa "komik adalah urutan-urutan gambar yang ditata sesuai tujuan dan 
1048 Pengembangan Media Pembelajaran Kodig Untuk Meningkatkan Prestasi Belajar Siswa di Sekolah Dasar - Unik Kurniawati, Henny Dewi Koeswanti

DOI : https://doi.org/10.31004/basicedu.v5i2.843

filosofi pembuatnya hingga pesan cerita tersampaikan, komik cenderung diberi lettering yang diperlukan sesuai dengan kebutuhan.”. Mochtar Lubis (dalam Bonneff, 1998:99) menyatakan bahwa komik merupakan salah satu alat komunikasi yang memberi pendidikan bagi semua kalangan. Poerwanto (dalam Hamdu, G. Agustina, 2011:3) mengemukakan pengertian prestasi belajar yaitu merupakan hasil yang dicapai dalam usaha belajar yang dinyatakan dalam raport.

\section{METODE}

Penelitian diakukan untuk mengetahui peningkatan prestasi belajar tema 6 subtema 1 pada siswa kelas $\mathrm{V}$ melalui media komik digital sebagai media pembelajaran. Rencana pelaksanaan penelitian dilakukan berdasarkan pengamatan yang dilakukan di SD N Mangunsari 02 Salatiga. Metode yang digunakan dalam penelitian dilakukan menggunakan jenis penelitian dan pengembagan (Research and Development) atau dapat disingkat dengan $R \& D$ yang merupakan metode yang digunakan untuk menguji dan mengembangkan sebuah produk, sesuai dengan pernyataan dari Borg and Gall (dalam Sugiyono, 2015:28) "What is research and development? It is a process used to develop and validate educational product". Langkah yang dilakukan sesuai dengan adaptasi dari (Sukmadinata, 2016) Terlebih dahulu dilakukan studi pendahuluan pada tahap pertama penelitian dilakukan. Pada tahap ini, dilakukan studi pustaka dan survey lapangan, sehingga dapat mengetahui masalah yang ada, dan cara untuk mengatasi permasalahan dalam proses pembelajaran. Instrumen pengumpulan data dengan cara observasi, wawancara, dan studi dokumenter.

Setelah mengetahui masalah, merancang media, maka hal selanjutnya yang dilakukan yaitu melakukan uji validasi pada media pembelajaran. Teknik analisis data uji validasi ahli materi dengan menggunakan teknik deskriptif kualitatif dan presentase. Hal tersebut dilakukan untuk menunjukkan tingkat validitas materi pada media pembelajaran kodig yang bertujuan untuk meningkatkan prestasi belajar Tema 6 Subtema 1 pada siswa kelas $\mathrm{V}$ dengan cara melihat hasil skor pengukuran yang diperoleh dari ahli materi dan ahli media. Model pengembangan disesuaikan dengan model penelitian dan pengembangan yaitu dengan model pengembangan ADDIE menurut Branch (dalam Mawardi, 2014) yaitu melalui tahap analisis, perencanaan, pengembangan, implementasi, dan evaluasi. Dalam penelitian hanya dilakukan hingga tahap pengembangan.

\section{HASIL DAN PEMBAHASAN}

Media pembelajaran Kodig merupakan sebuah media pembelajaran berupa komik digital yang dalam prosesnya dapat digunakan melalui gadget. Penggunaan media Kodig dalam proses belajar mengajar pada siswa kelas V Tema 6 Subtema 1 diharapkan dapat membantu meningkatkan prestasi belajar siswa, motivasi, serta semangat untuk belajar dan membaca. Langkah-langkah pengembangan media pembelajaran Kodig dilakukan dengan model pengembangan ADDIE, yang melalui beberapa tahap, yaitu tahap: (1) Analisis, (2) Perancangan, (3) Pengembangan, (4) Implementasi, dan (5) Evaluasi.

Pada penelitian ini, dikarenakan berbagai hal terutama karena masa pandemi dan diberlakukan PSBB (pembatasan sosial bersekala besar) hingga PPKM(pemberlakuan pembatasan kegiatan masyarakat), maka langkah-langkah penelitian hanya dilakukan hingga tahap pengembangan. Lebih jelas mengenai tahap yang dilakukan dalam pengembangan media Kodig sebagai berikut:

\section{Tahap Analisis}

Tahap analisis merupakan tahap awal dalam langkah pengembangan model ADDIE. Pada tahap analisis, diketahui bahwa guru beserta siswa membutuhkan media pembelajaran yang inovatif guna membantu dalam proses pemberian dan penerimaan materi pembelajaran, serta meningkatkan motivasi dan semangat dalam belajar, terutama ketika pembelajaran dilakukan secara daring. Dikembangkan media pembelajaran Kodig 
untuk membantu permasalahan yang dihadapi oleh siswa dan guru, yang telah disesuaikan dengan kompetensi dan kurikulum yang ada.

2. Tahap perencanaan

Dilakukan tahap perencanaan, dimana dilakukan analisis materi dan kompetensi dasar. Setelah mengentahui kompetensi dasar dan materi yang harus diajarkan, perancangan indikator dan tujuan pembelajaran dilakukan.

\section{Tahap pengembangan}

Terdapat empat langkah dalam tahap pengembangan, yaitu: pra pengembangan, penyusunan draft, review edit, dan revisi.

Pada tahap pra pengembangan, dilakukan penulisan skrip atau naskah untuk komik. Penulisan gambaran percakapan yang akan dimasukkan dalam komik.

Tahap kedua yaitu penyusunan draft. Proses gambar sketsa dan pemberian warna pada komik, dapat dilihat pada gambar berikut:

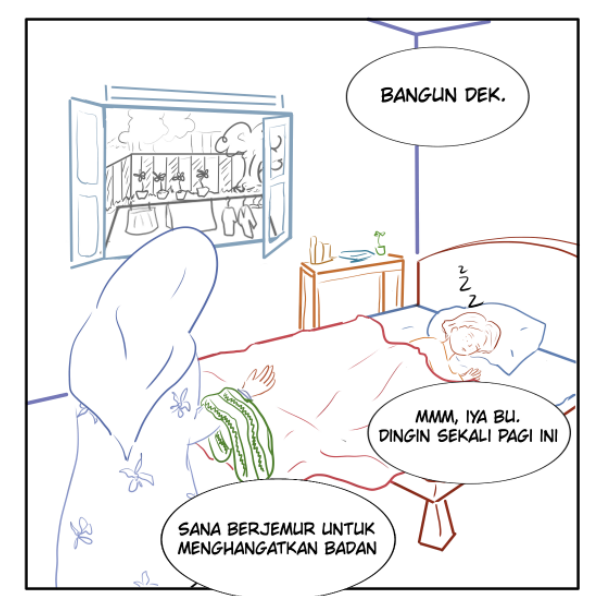

Gambar 1. Gambar Sketsa 1

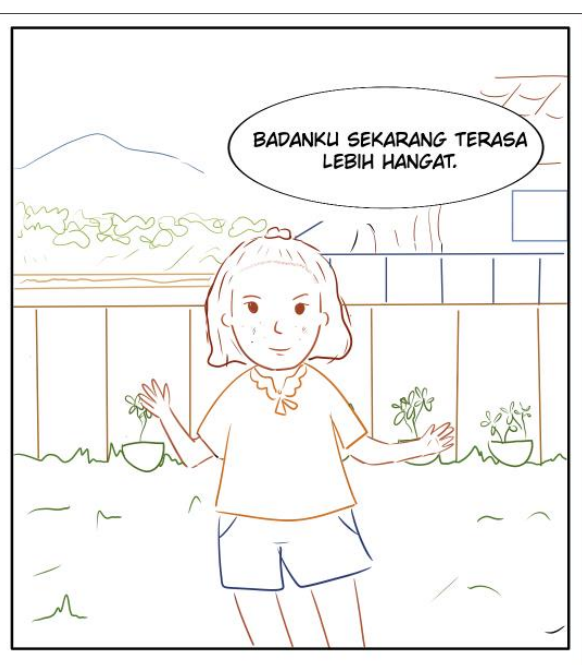

Gambar 3. Gambar Sketsa 2

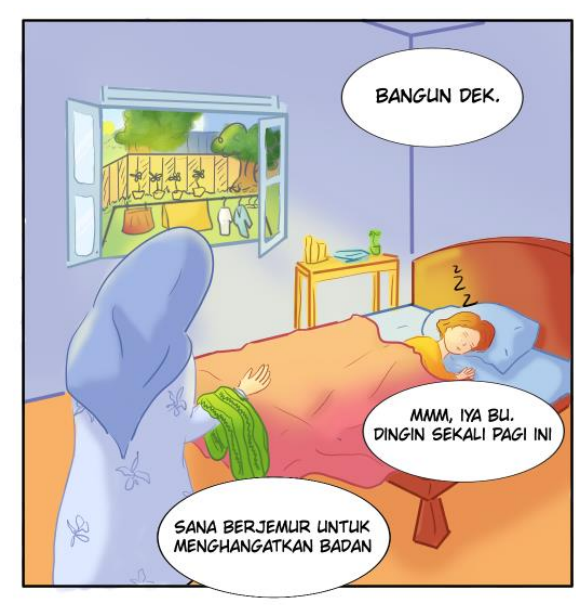

Gambar 2. Gambar Pewarnaan 1

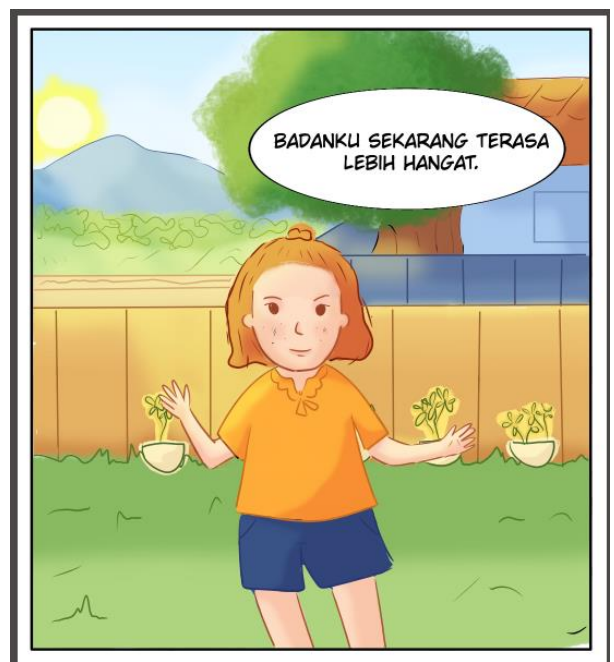

Gambar 4. Gambar Pewarnaan 2 
DOI : https://doi.org/10.31004/basicedu.v5i2.843

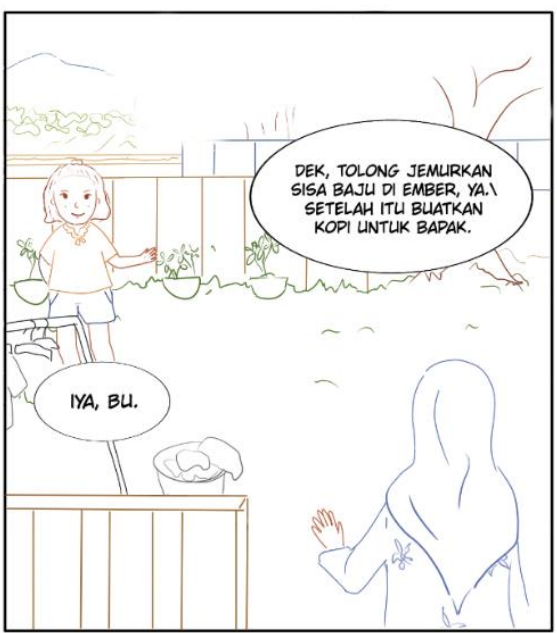

Gambar 5. Gambar Sketsa 3

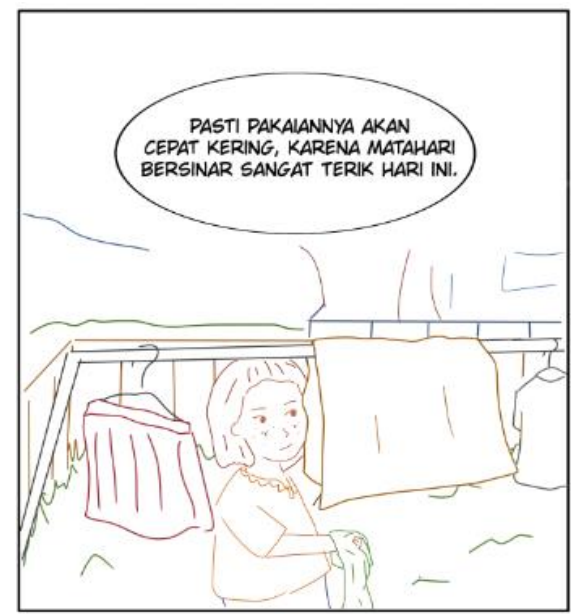

Gambar 7. Gambar Sketsa 4

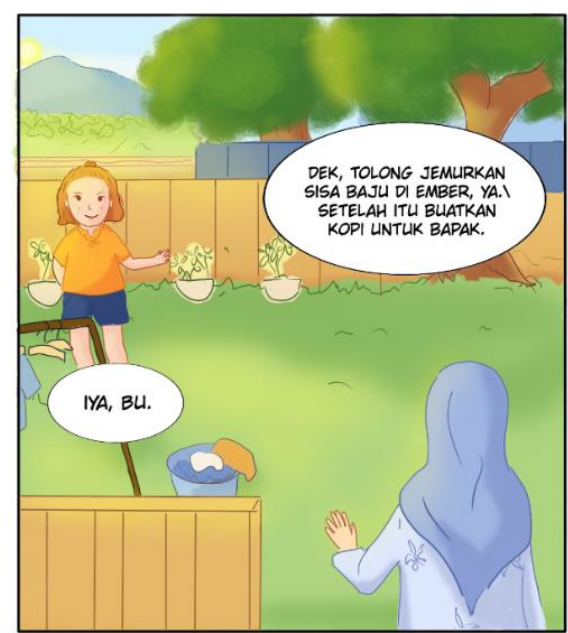

Gambar 6. Gambar Pewarnaan 3

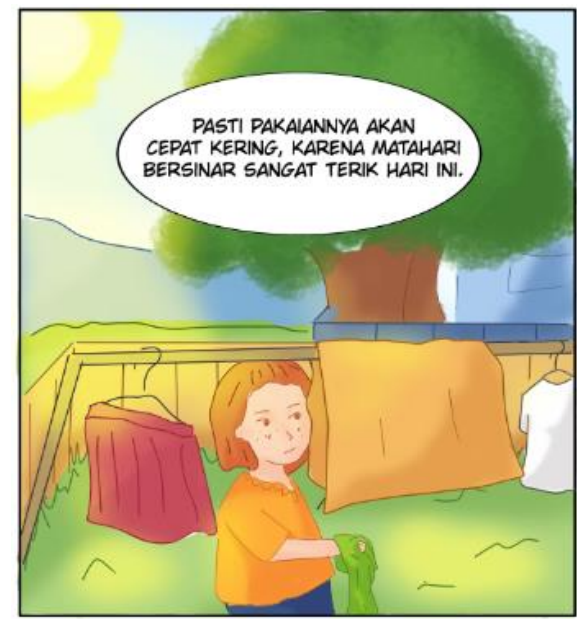

Gambar 8. Gambar Pewarnaan 4

Tahap ketiga yaitu review-edit. Dilakukan validasi materi dan validasi media.

Validasi ahli materi pada media Kodig oleh dosen dari program studi Pendidikan Guru Sekolah Dasar, Fakultas Keguruan dan Ilmu Pendidikan, Universitas Kristen Satya Wacana, yaitu Agustina Tyas Asri Hardini, S.Pd., M.Pd. Validasi dilakukan dengan memberikan angket validasi pernyataan dengan skor maksimal 5 dan skor minimal 1, serta media pembelajaran kepada ahli. Hasil dari validasi ahli materi disajikan dalam tabel berikut:

Tabel 1

Validasi Ahli Materi

\begin{tabular}{|l|l|l|}
\hline Aspek & Indikator & Skor \\
\hline Materi & Kesesuaian cerita dengan materi pembelajaran & 4 \\
\hline & Kesesuaian uraian materi dalam komik dengan kompetensi dasar & 4 \\
\hline & Kesesuaian dengan indikator pembelajaran & 4 \\
\hline & Kesesuaian dengan tujuan pembelajaran bagi kelas V & 4 \\
\hline & Kejelasan konsep materi pembelajaran & 4 \\
\hline & Kelengkapan materi yang disajikan & 5 \\
\hline
\end{tabular}




\begin{tabular}{|l|l|l|}
\hline & Ketepatan pemilihan gambar dengan penyajian gambar & 5 \\
\hline & Kesesuaian ilustrasi cerita dengan materi pembelajaran & 5 \\
\hline & Keruntutan cerita dengan materi & 4 \\
\hline & Alur cerita relevan dengan kompetensi yang harus dikuasai siswa & 4 \\
\hline & Alur cerita dapat mendukung perkembangan karakter siswa & 4 \\
\hline & Alur cerita yang disajikan sesuai dengan kehidupan sehari-hari & 5 \\
\hline & Penyajian materi dapat mendorong rasa keingintahuan siswa. & 3 \\
\hline & Penyajian materi dapat mendorong siswa mengamalkan isi bacaan & 4 \\
\hline & $\begin{array}{l}\text { Penyajian materi dapat mendorong siswa membangun } \\
\text { pengetahuannya sendiri. }\end{array}$ & 4 \\
\hline & Kesesuaian dengan kaidah EYD Bahasa Indonesia & 5 \\
\hline & Bahasa jelas dan mudah dimengerti & 4 \\
\hline & Konsistensi penggunaan bahasa tidak baku dalam cerita & 4 \\
\hline & Keefektifan kalimat dalam media yang disajikan & 4 \\
\hline & Kesesuaian bahasa dengan tingkat perkembangan peserta didik & 4 \\
\hline & Jumlah & 84 \\
\hline & Persentase & $84 \%$ \\
\hline
\end{tabular}

Dengan tambahan kritik dan saran, yaitu: secara keseluruhan media KODIG yang dibuat menarik dan isi materi sesuai dengan tujuan pembelajaran. Serta kesimpulan yang diberikan dalam uji validasi, yaitu: media layak digunakan tanpa revisi.

Perhitungan hasil validasi sebagai berikut:

$$
A P=\frac{\text { Skor Aktual }}{\text { Skor Ideal }} \times 100 \%
$$

Dengan keterangan:

AP

Skor Aktual

Skor Ideal
: Angka Persentase

: Skor yang diberikan oleh validator ahli

: Skor maksimal hasil kali jumlah item dari masing-masing item

AP (Angka Persentase) yang telah diperoleh kemudian dikelompokkan dalam beberapa kategori seperti pada tabel berikut:

Tabel 2 Kategori AP

\begin{tabular}{|l|l|}
\hline \multicolumn{1}{|c|}{ Interval } & \multicolumn{1}{c|}{ Kategori } \\
\hline $81-100 \%$ & Sangat Tinggi \\
\hline $61-80 \%$ & Tinggi \\
\hline $41-60 \%$ & Cukup \\
\hline $21-40 \%$ & Rendah \\
\hline $0-20 \%$ & Sangat Rendah \\
\hline
\end{tabular}


1052 Pengembangan Media Pembelajaran Kodig Untuk Meningkatkan Prestasi Belajar Siswa di Sekolah Dasar - Unik Kurniawati, Henny Dewi Koeswanti

DOI : https://doi.org/10.31004/basicedu.v5i2.843

Dari data tabel menunjukkan perolehan jumlah skor 84 dengan presentase $84 \%$ dari 20 item pernyataan yang terbagi dari 15 item aspek materi dan 5 item aspek bahasa. Dengan hasil demikian, diketahui bahwa media Kodig berada pada interval 81-100\% dan dapat dikategorikan sangat tinggi sehingga layak untuk digunakan, sejalan dengan kesimpulan yang diberikan.

Selanjutnya dilakukan validasi ahli media pada media Kodig oleh dosen dari program studi Pendidikan Guru Sekolah Dasar, Fakultas Keguruan dan Ilmu Pendidikan, Universitas Kristen Satya Wacana, yaitu Elvira Hoesein Radia, S.Pd., S.Mus., M.Pd. Validasi dilakukan dengan memberikan angket validasi pernyataan dengan skor maksimal 5 dan skor minimal 1, serta media pembelajaran kepada ahli. Hasil dari validasi ahli media disajikan dalam tabel berikut:

Tabel 3

Validasi Ahli Media

\begin{tabular}{|c|c|c|}
\hline Aspek & Indikator & Skor \\
\hline \multirow[t]{7}{*}{ Tampilan } & Relevansi konten materi pembelajaran & 4 \\
\hline & Kemenarikan background & 4 \\
\hline & Relevansi gambar dengan materi & 4 \\
\hline & Proporsi warna pada ilustrasi sesuai & 4 \\
\hline & Ilustrasi gambar memperjelas latar dan rangkaian cerita & 3 \\
\hline & Kesesuaian media sebagai sumber belajar & 4 \\
\hline & Kemampuan media dalam menarik perhatian siswa & 4 \\
\hline \multirow[t]{5}{*}{ Interaksi } & Tersedianya fasilitas & 3 \\
\hline & Kesesuaian materi dengan topik & 4 \\
\hline & Kesesuaian media dengan karakteristik siswa & 4 \\
\hline & Kemampuan media dalam mengembangkan motivasi belajar & 4 \\
\hline & Alur cerita dapat membantu memahami dan mengulang materi & 4 \\
\hline \multirow[t]{4}{*}{ Kontrol } & Kemudahan penggunaan media & 4 \\
\hline & Kemudahan akses tombol panel & 4 \\
\hline & Efisiensi media dalam kaitannya dengan biaya & 4 \\
\hline & Efisiensi media dalam kaitannya dengan waktu & 4 \\
\hline \multirow[t]{6}{*}{ Bentuk } & Kualitas media & 4 \\
\hline & Kesesuaian animasi dengan materi & 4 \\
\hline & Kemudahan virtual classroom & 3 \\
\hline & Media dapat digunakan sebagai sumber belajar & 4 \\
\hline & Jumlah & 77 \\
\hline & Persentase & $77 \%$ \\
\hline
\end{tabular}

Dengan kritik dan saran, sebagai berikut: Untuk mengajarkan menjaga kebersihan lingkungan gambar sampah berserakan dipinggir laut lebih diperjelas. Sehingga kesimpulan yang diberikan yaitu: Media layak digunakan dengan revisi. 
1053 Pengembangan Media Pembelajaran Kodig Untuk Meningkatkan Prestasi Belajar Siswa di Sekolah Dasar - Unik Kurniawati, Henny Dewi Koeswanti

DOI : https://doi.org/10.31004/basicedu.v5i2.843

Dilakukan perhitungan sama dengan perhitungan pada uji validasi ahli materi. Dari data tabel menunjukkan perolehan jumlah skor 77 dengan presentase $77 \%$ dari 20 item pernyataan yang terbagi dari 7 item aspek tampilan, 5 item aspek interaksi, 4 item aspek kotrol, dan 4 item aspek bentuk.

Dengan hasil demikian, diketahui bahwa media Kodig berada pada interval 61-80\% dan termasuk dalam kategori tinggi sehingga layak untuk digunakan, sejalan dengan kesimpulan yang diberikan.

Sesuai dengan kesimpulan dari ahli materi dan ahli media, maka dilakukan revisi sesuai kritik dan saran dari ahli media yaitu untuk mengajarkan menjaga kebersihan lingkungan gambar sampah berserakan dipinggir laut lebih diperjelas, sehingga dapat diketahui revisi pada media Kodig sebagai berikut:

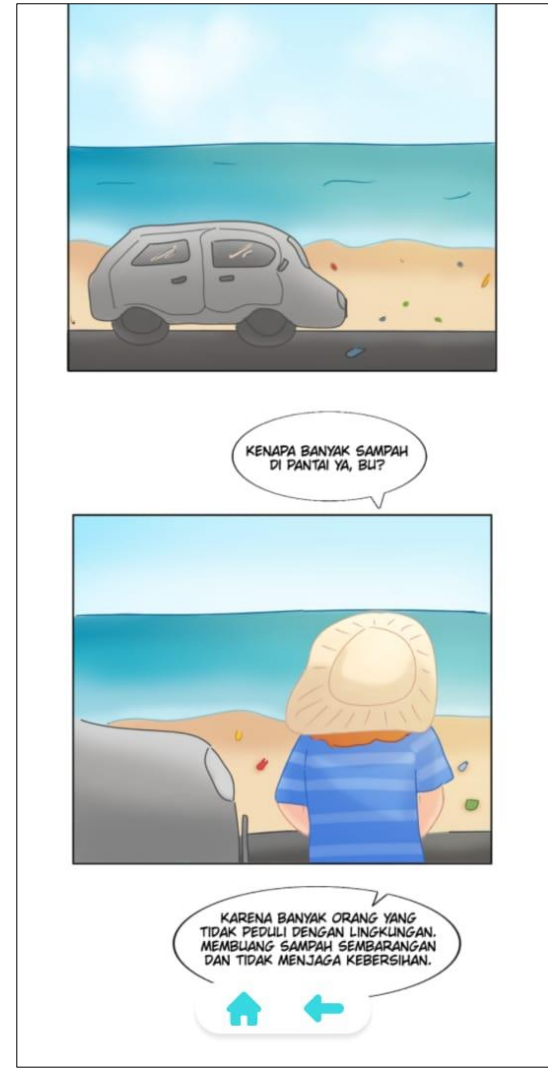

Gambar 9. Sebelum Revisi 1

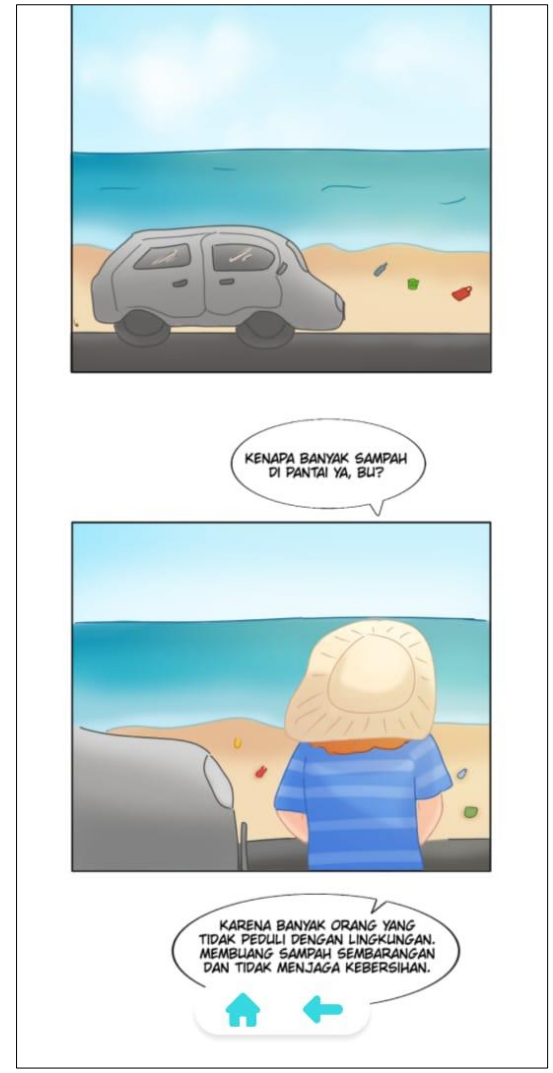

Gambar 10. Setelah Revisi 1 
1054 Pengembangan Media Pembelajaran Kodig Untuk Meningkatkan Prestasi Belajar Siswa di Sekolah Dasar - Unik Kurniawati, Henny Dewi Koeswanti

DOI : https://doi.org/10.31004/basicedu.v5i2.843

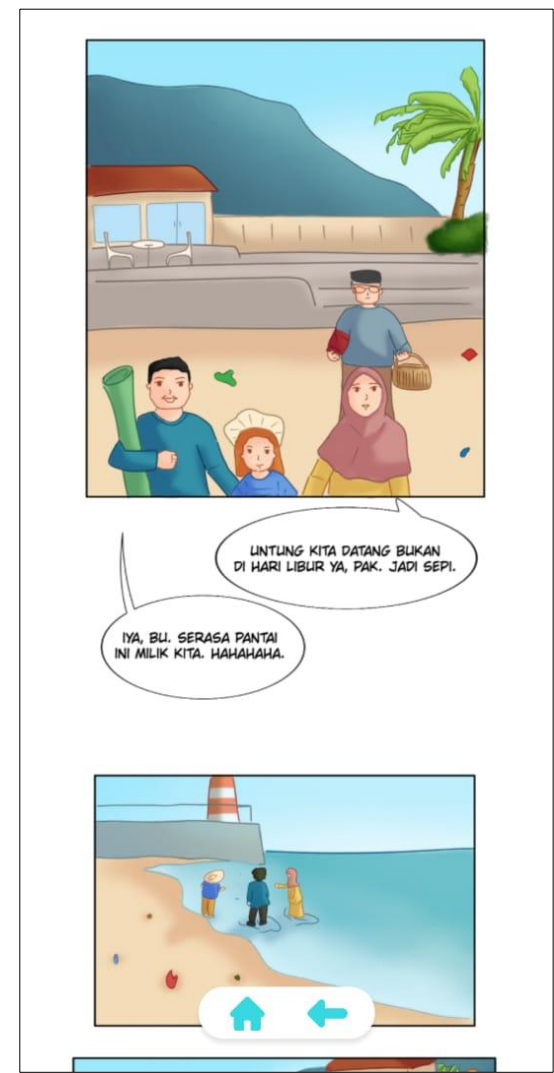

Gambar 11. Sebelum Revisi 2

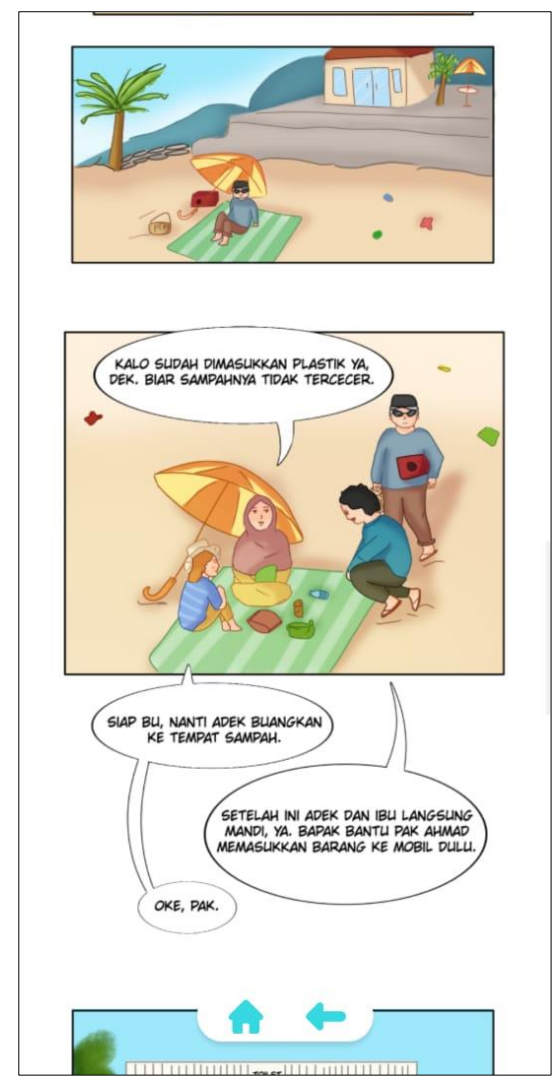

Gambar 13. Sebelum Revisi 3

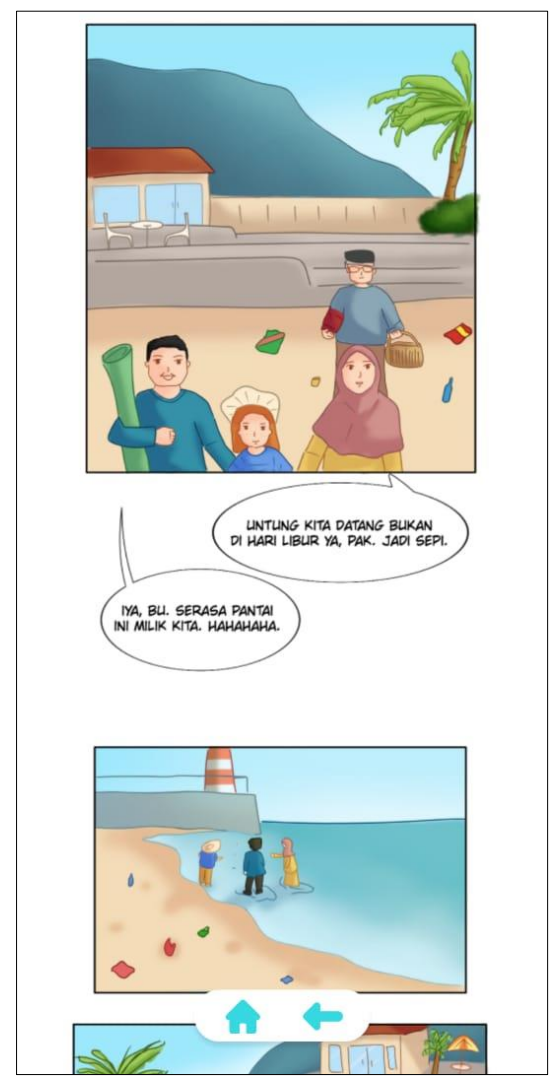

Gambar 12. Setelah Revisi 2

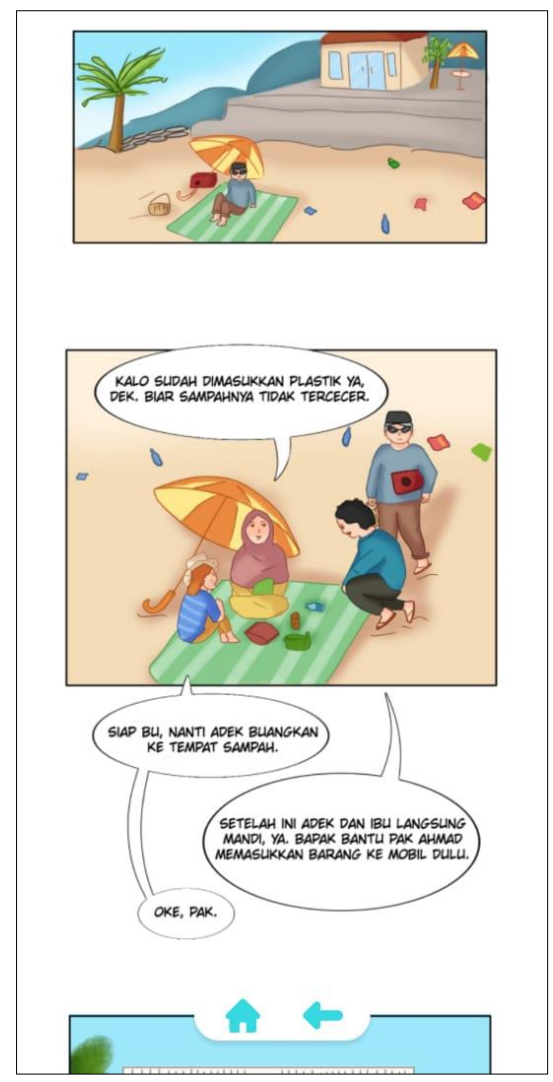

Gambar 14. Setelah Revisi 3 
1055 Pengembangan Media Pembelajaran Kodig Untuk Meningkatkan Prestasi Belajar Siswa di Sekolah Dasar - Unik Kurniawati, Henny Dewi Koeswanti

DOI : https://doi.org/10.31004/basicedu.v5i2.843

Spesifikasi Produk

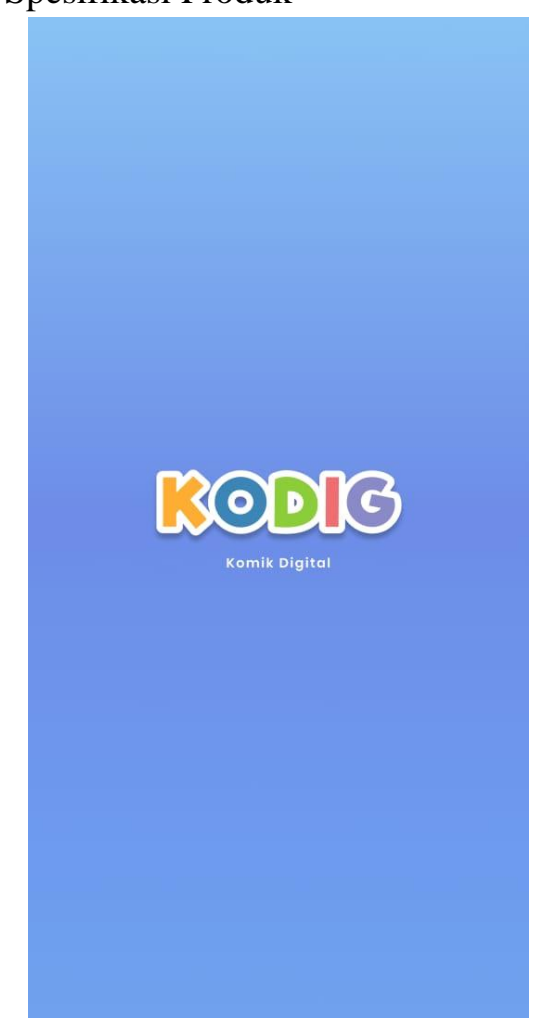

Sebelum masuk ke aplikasi, ditampilkan tampilan pembuka berupa ikon aplikasi Kodig selama 3 detik.

\section{Gambar 15. Tampilan Pembuka}

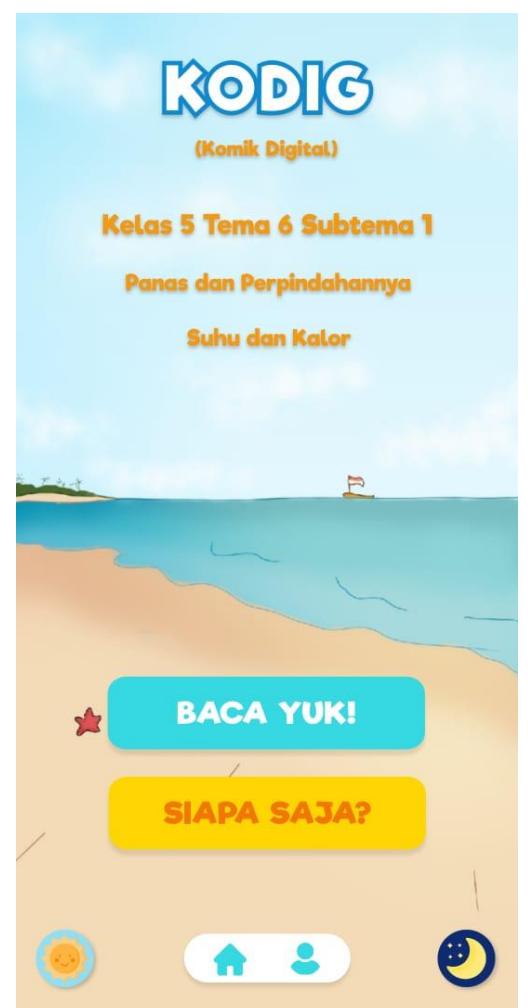

\section{Gambar 16. Tampilan Menu Utama 1}

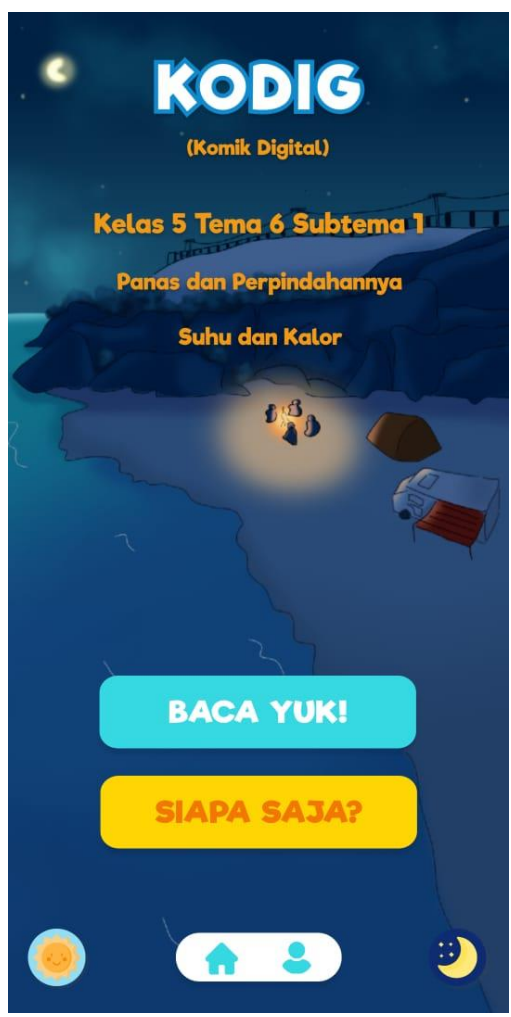

Gambar 17. Tampilan Menu Utama

Pada tampilan awal terdapat 2 background, dapat disebut mode siang dan mode malam. Untuk mengganti mode siang atau malam, dapat di klik pada gambar (matahari) untuk mode siang, dan gambar ${ }^{\mathcal{O}}$ (bulan) 
1056 Pengembangan Media Pembelajaran Kodig Untuk Meningkatkan Prestasi Belajar Siswa di Sekolah Dasar - Unik Kurniawati, Henny Dewi Koeswanti

DOI : https://doi.org/10.31004/basicedu.v5i2.843

untuk mode malam.

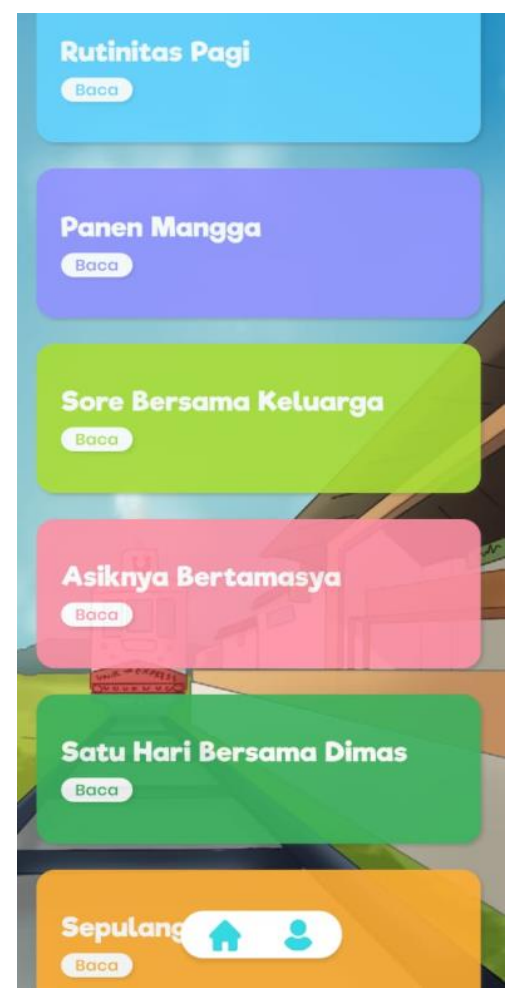

Gambar 18. Tampilan "Baca Yuk!"

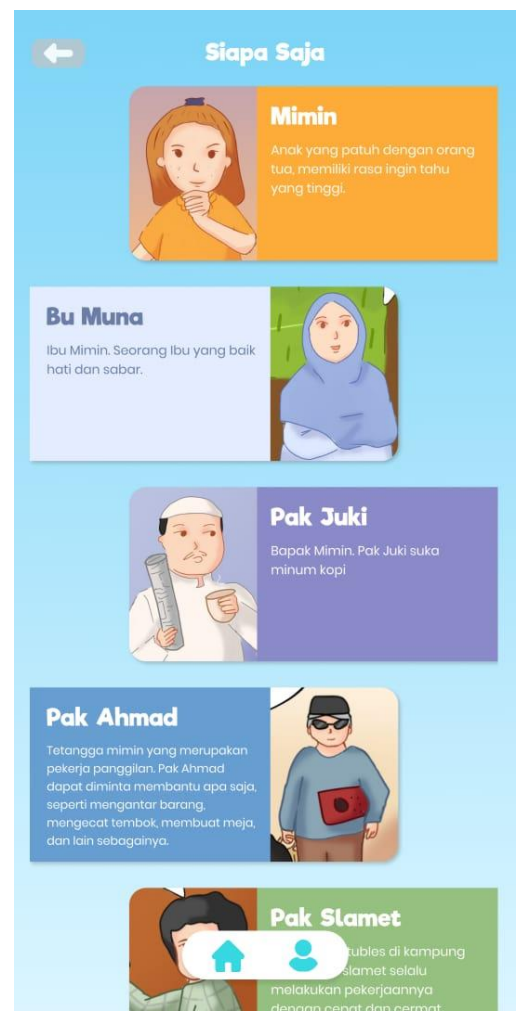

Gambar 19. Tampilan "Siapa Saja?"
Tampilan

\section{BACA YUK!}

berisikan beberapa judul mengenai cerita yang akan dibaca oleh siswa. Cerita dapat dipilih secara urut ataupun sesuai dengan keinginan.
Tampilan SIAPA SAJA? berisikan tokoh yang terdapat dalam cerita serta beberapa penjelasan singkat. 
1057 Pengembangan Media Pembelajaran Kodig Untuk Meningkatkan Prestasi Belajar Siswa di Sekolah Dasar - Unik Kurniawati, Henny Dewi Koeswanti

DOI : https://doi.org/10.31004/basicedu.v5i2.843

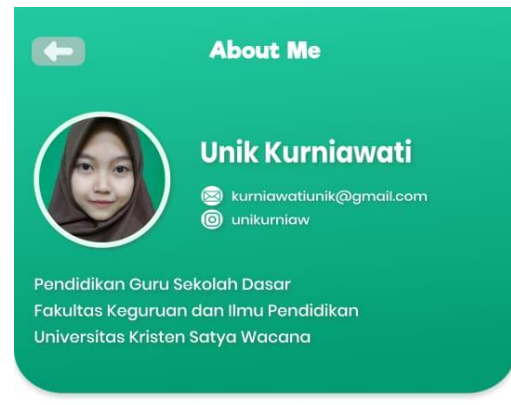

KODIG (Komik Digital) merupakan cerita bergambar
yang berisikan informasi melalui media elektronik.

KODIQ berisikan materi pembelajaran kelas 5 Tema 6 (Panas dan Porpindahannya) Subtoma I (Suhu dan Kalor)

Pembelajaran : Rutinitas Pagi

Pembelajaran 3: - Panen Mangga

Pombelajaran 4: Sore Bersama Keluarg

Pembelajoran 5. Satu Hari Bersama Dim

Pembelajaran 6: Sepulang Sekolah

Diharapkan dapat membantu guru dalam proses belajar

mengajar. Serta membantu siswa memahami materi

dengan cara yang lebih menyenangkan

Kritik dan Saran yang membangun sangat diperlukan.

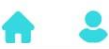

\section{Gambar 20. Tampilan "About Me"}

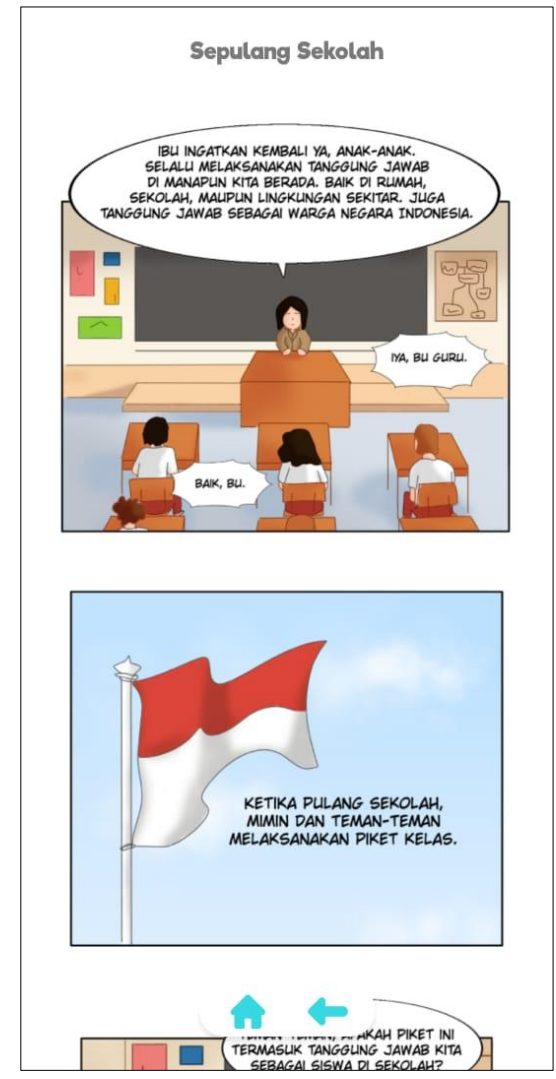

Gambar 21. Tampilan Cerita 1
Tampilan "About Me" dengan ikon

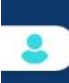
berisikan beberapa penjelasan, yaitu mengenai siapa pembuat aplikasi, pengertian dari aplikasi KODIG, materi yang terdapat dalam cerita, penjelasan cerita berkaitan dengan pembelajaran, serta keinginan dan harapan.

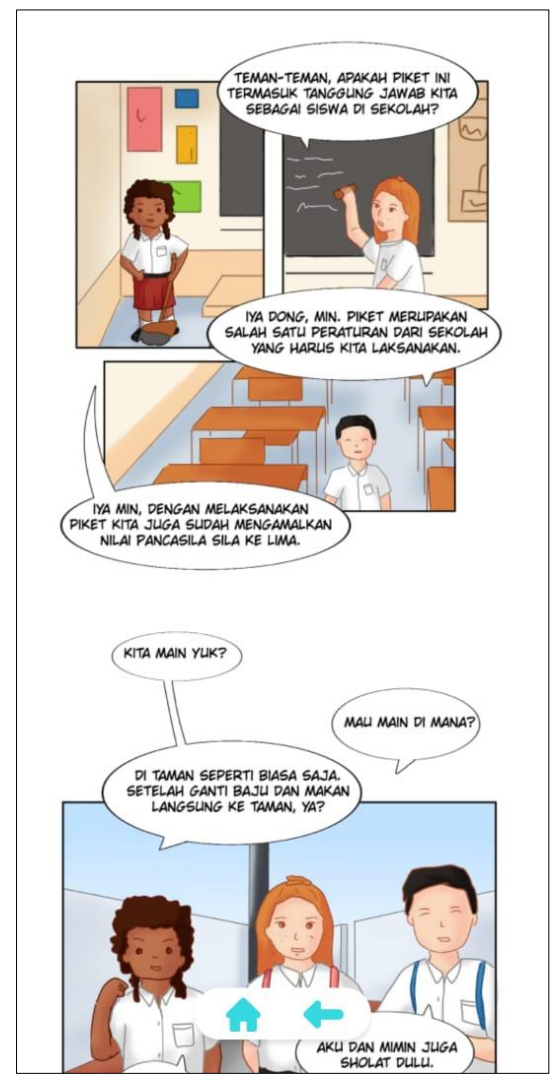

Gambar 22. Tampilan Cerita 2 


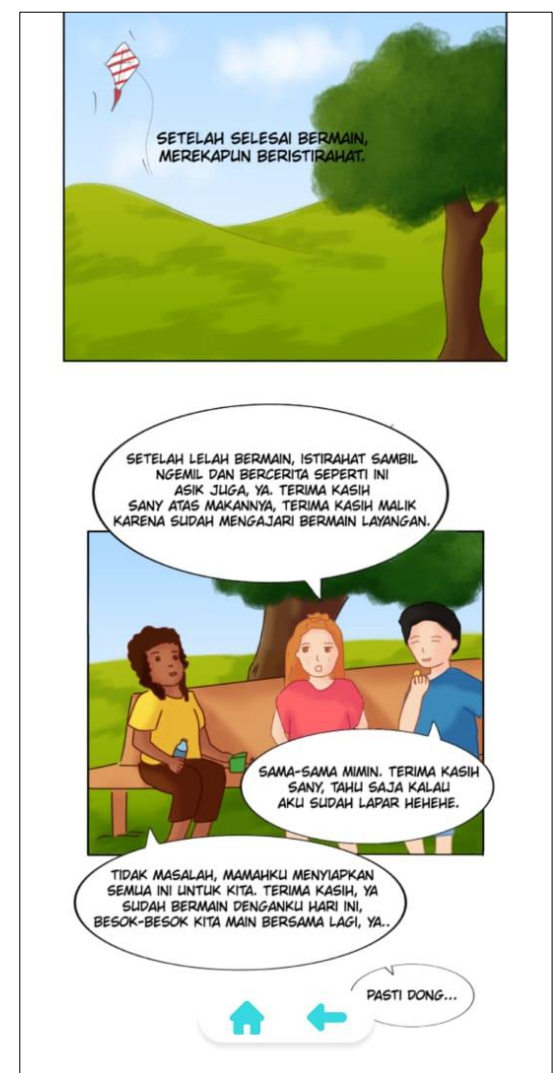

Gambar 23. Tampilan Cerita 3

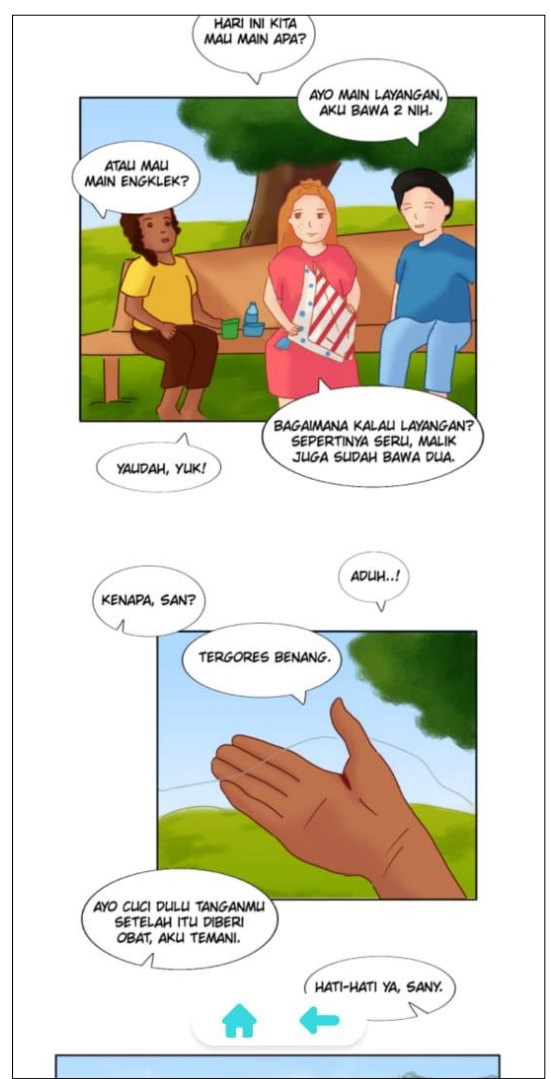

Gambar 24. Tampilan Cerita 4

Salah satu contoh tampilan cerita dalam komik dengan berbagai tokoh dan berbagai karakter. Berisikan cerita yang relevan dengan materi pembelajaran Tema 6 Subtema 1.

\section{KESIMPULAN}

Simpulan menyajikan ringkasan dari uraian mengenai hasil dan pembahasan, mengacu pada tujuan penelitian. Berdasarkan kedua hal tersebut dikembangkan pokok-pokok pikiran baru yang merupakan esensi dari temuan penelitian. Berdasarkan hasil penelitian dan pembahasan, dapat disimpulkan beberapa hal:

1. Pengembangan media pembelajaran komik dalam meningkatkan prestasi belajar Tema 6 Subtema 1 untuk siswa kelas V dapat dikembangkan menggunakan desain pengembangan ADDIE dengan 4 tahapan yaitu analisis, perancangan, pengembangan, dan uji coba. Dalam penelitian tidak dilaksanakan uji coba, kegiatan hanya dilakukan hingga tahap pengembangan.

2. Media pembelajaran komik dalam meningkatkan prestasi belajar Tema 6 Subtema 1 untuk siswa kelas V dinyatakan valid. Dilakukan uji validasi oleh ahli media dan ahli materi. Hasil validasi pada uji ahli materi memeroleh hasil dengan skor 84 dengan persentase $84 \%$ dan dapat dikategorikan sangat tinggi. Hasil validasi pada uji ahli media memeroleh hasil dengan skor 77 dengan persentase $77 \%$, dan dapat dikategorikan tinggi. Maka dari hasil uji ahli yang dilaksanakan, dapat disimpulkan bahwa media komik layak diguakan.

\section{DAFTAR PUSTAKA}

Ambaryani. (2017). Pengembangan Media Komik untuk Efektifitas dan Meningkatkan Hasil Belajar Kognitif Materi Perubahan Lingkungan Fisik Kelas IV SDN 1 Ngangrong. Repositori UKSW. 
1059 Pengembangan Media Pembelajaran Kodig Untuk Meningkatkan Prestasi Belajar Siswa di Sekolah Dasar - Unik Kurniawati, Henny Dewi Koeswanti

DOI : https://doi.org/10.31004/basicedu.v5i2.843

Andra, L. (2018). Pengembangan Media Komik dan Kartu Disiplin pada Pembelajaran Karakter Tema 6 Kelas 3 Sekolah Dasar Negeri Salatiga 09. Repositori UKSW.

Arsyad, A. (2011). Media Pembelajaran (p. 3). PT Raja Grafindo Persada.

Bonneff, M. (1998). Komik Indonesia. Kepustakaan Populer Gramedia.

Departemen Pendidikan Nasional. (2006). Strategi Pembelajaran yang Mengaktifkan Siswa (p. 6). Depdiknas.

Gumelar. (2011). Comic Making. PT Indeks.

Hamdu, G. Agustina, L. (2011). Pengaruh Motivasi Belajar Siswa terhadap Prestasi Belajar IPA di Sekolah Dasar. Jurnal Penelitian Pendidikan, 12(1), 90-96.

Hidayah, N. (2017). Pengembangan Media Pembelajaran Berbasis Komik pada Mata Pelajaran Ilmu Pengetahuan Sosial Kelas IV MI Nurul Hidayah Roworejo Negerikaton Pasarawan. Jurnal Pendidikan Dan Pembelajaran Dasar, 4(1), 34-46.

Kristiani. (2017). Pengembangan Komik Interaktif Berbasis Discovery Learning untuk Pembelajaran Materi Pecahan Siswa Kelas V Sekolah Dasar. Repositori UKSW.

Mawardi. (2014). Penelitian dan Pengembangan (Research and Development/R\&D).

Mentari, S. (2017). Pengembangan Komik Edukasi untuk Meningkatkan Hasil Belajar Siswa tentang Materi Perbandingan untuk Kelas V SD. Repository UKSW.

Permendikbud Nomor 22 Tahun 2016 tentang Standar Proses Pendidikan Dasar dan Menengah. (n.d.).

Prastowo, A. (2013). Pengembangan Bahan Ajar Tematik. DIVA Pres. Rosda Karya.

Sugiyono. (2015). Metode Penelitian Kuantitatif, Kualitatif, dan R\&D. Alfabeta.

Sukmadinata, N. . (2016). Metode Penelitian Pendidikan. Remaja.

Wardana, A. (2018). Pengembangan Komik sebagai Media Pembelajaran untuk Mengapresiasi Cerita Anak Pada Peserta Didik Kelas III SD/MI. Doctoral disserstation, UIN Raden Intan. 